連続側流清净方式

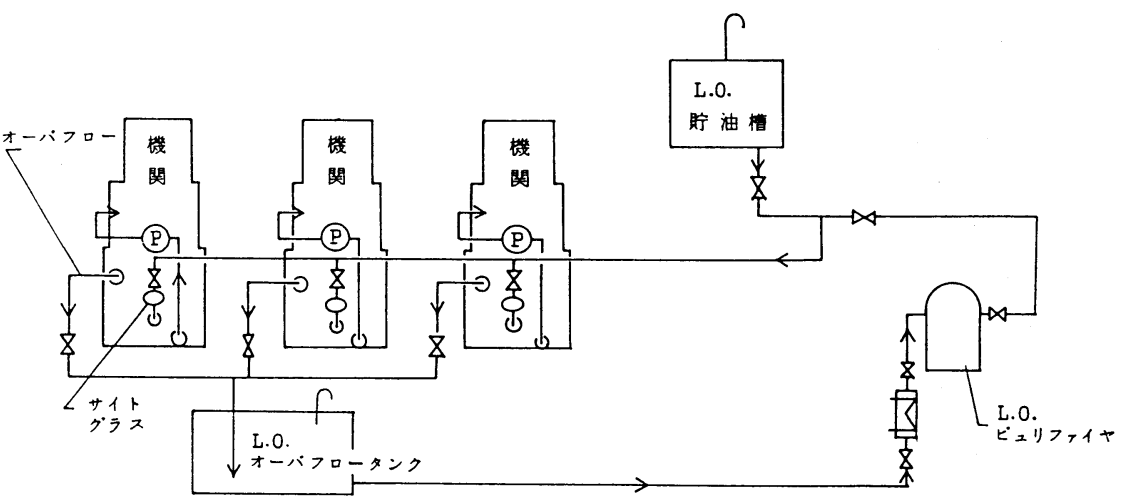

図 3 潤滑油システム(例)

$2 l / \mathrm{PS}$ 以上, 連続側流清浄として TBNを 7 以上に保 つととで好結果を得ている．今後共この方式で充分対応 できると考えている.

補機はサンプタンクを共通台板にもうける関係で張込 量が小さく，バイパスフィルターを併用したバッチ処理 が行われて来たが今後 1500〜3500 秒油に対応するため にはTBNを増すのみでは不充分であり，連続清净方式 に変更し, サンプタンク容量を増加する必要がある. 当 社では補機配置据付の特殊性を考慮して図 3 の上うな連 続清浄方式を推奖している.

\section{4. あとがき}

将来燃料に関するCIMAC PROPOSALが決定され,
ISO規格の制定あ大詰めに来ている由である.

多くの研究成果も相ついで発表され将来燃料の正体が次 第に明らかになっている.

しかしながら先行はとあかく, 現状はそれ程出回って いるわけではないから，サンプルオイルによるベンチで の確認と現状燃料での実績をもとにして予想される障害 に対し可能な限りの対応を行い, エンジンメーカとして の務めを果たす所存である.

\section{文献}

1）舶用機関学会誌, Vol. 15, No. 2, 1980-2, p. 142

2）創立 10 周年記念事業講演会前刷， p. 11，1982-3

\title{
12. 阪神内燃機工業(株)*
}

\section{正 橋 三津夫**}

\section{1.はじめに}

昭和 52 年の第 2 次石油ショック以来の石油需給のひ っ迫と石油価格の高騰により，舶用機関は急激に低質燃 料油の使用を余儀無くされている.

とくに当社の製品があっとも多くのシェアーを占める 内航船の燃料油に扔いて低質化の変化は最む著しく, 主 機関出力 1200 PS 1300 PSであ 1500 秒油 (RW. No. $1,100{ }^{\circ} \mathrm{F}$ )を専焼する船が出てきている. しかし取扱い が適切でないと長時間使用後におけるシリンダライナー やピストンリングの摩耗の増大, 排気弁や燃料弁の耐久 性の低下などを生じ，その結果メンテナンス間隔が極端

* 原稿受付 昭和 57 年 4 月 22 日

** 正会員 阪神内燃機工業(株) (明石市貴崎 5-8-70)

日本舶用機関学会誌 第 17 巻 第 9 号
に短くなって運航に支障をきたしたり，ひいては機関の 寿命㳊響してくる.

そこでてのような支障をできるだけ少なくして良質燃 料使用時のメンテナンス間隔に近づけるべく，機関その あのが低質燃料油の使用に適する新形機関を開発し又は 在来機関の改造を行う之同時に, 燃料油, 潤滑油及び冷 却水系統を始め機関室全体の装備と機能を十分ととのえ るととが必要である.

\section{2. 燃料油の低留化対策}

（1）機関単体の仕様 低質燃料油が機関に与える悪 影響を長期間にわたり調查研究し，機関のとるべき対策 を検討してきた.

表 1 亿低質燃料油使用時の機関仕様を示し, 表 2 にて 
表 1 低質燃料油別の機関特別仕様

\begin{tabular}{|c|c|c|c|c|c|c|}
\hline \multirow{2}{*}{ No. } & 使用燃料油 & $\mathrm{cSt}, 50^{\circ} \mathrm{C}$ & 120 & 180 & $250 \sim 380$ & \multirow{2}{*}{ 記 } \\
\hline & 特別仕様 & R.W. No. $1,100^{\circ} \mathrm{F}$ & $1000^{\prime \prime}$ & $1500^{\prime \prime}$ & $2300^{\prime \prime} \sim 3500^{\prime \prime}$ & \\
\hline 1 & \multicolumn{2}{|c|}{$\begin{array}{l}\text { 全清水冷却方式とし，自動温度 調整弁 (空気式 } \\
\text { を推奖する)を装備する. }\end{array}$} & $\bigcirc$ & $\mathrm{O}$ & O & $\begin{array}{l}\text { 低負荷運転をしないあ } \\
\text { のについてッックス } \\
\text { 式でもよい. }\end{array}$ \\
\hline 2 & \multicolumn{2}{|c|}{$\begin{array}{l}\text { 燃料供給ポンプを独立モーター駆動とし，ポン } \\
\text { プ能力をアップする. }\end{array}$} & $45 \mathrm{~m}$ & $45 \mathrm{~m}$ & $60 \mathrm{~m}$ & \\
\hline 3 & \multicolumn{2}{|c|}{$\begin{array}{l}\text { 燃料油主管端に調圧弁を装備し燃料油圧力をア } \\
\text { ップする. }\end{array}$} & $\begin{array}{r}1.0 \sim 1.5 \\
\left(\mathrm{~kg} / \mathrm{cm}^{2}\right) \\
\end{array}$ & $\begin{array}{r}1.0 \sim 1.5 \\
\left(\mathrm{~kg} / \mathrm{cm}^{2}\right) \\
\end{array}$ & $\begin{array}{l}3.5 \sim 4.5 \\
\left(\mathrm{~kg} / \mathrm{cm}^{2}\right)\end{array}$ & \\
\hline 4 & \multicolumn{2}{|c|}{ 燃料油 2 次とし器を 300 メッシュとする. } & $\mathrm{O}$ & 0 & 0 & \\
\hline 5 & \multicolumn{2}{|c|}{$\begin{array}{l}\text { 燃料油 } 2 \text { 次とし器をスティームジャケット付, } \\
\text { 然料油主管をスティームトレーシングする. } \\
\end{array}$} & - & 0 & O & $\begin{array}{l}\text { 電気ヒーティングあ可 } \\
\text { 能. }\end{array}$ \\
\hline 6 & \multicolumn{2}{|c|}{$\begin{array}{l}\text { 㶤料油ドレンパイプ等もスティームトレーシン } \\
\text { グする. }\end{array}$} & - & - & O & \\
\hline 7 & \multicolumn{2}{|c|}{ シリンダライナメッキをなくする. } & 0 & $\mathrm{O}$ & 0 & \\
\hline 8 & \multicolumn{2}{|c|}{ 排気弁にバルブローテータを装備する. } & $\mathrm{O}$ & $\mathrm{O}$ & $\mathrm{O}$ & \\
\hline 9 & \multicolumn{2}{|c|}{ 排気弁ガイドに自動注油する. } & - & - & $\mathrm{O}$ & \\
\hline 10 & \multicolumn{2}{|c|}{$\begin{array}{l}\text { 然料噴射ポンプを環流形とし，燃料油の循環を } \\
\text { 行う. }\end{array}$} & - & - & $\bigcirc$ & \\
\hline 11 & \multicolumn{2}{|c|}{$\begin{array}{l}\text { 吸気ドレーンセパレーターを装碏し, 吸気の除 } \\
\text { 湿を行う. }\end{array}$} & - & - & $\bigcirc$ & \\
\hline 12 & \multicolumn{2}{|c|}{ 燃料油処理系統に，とし器形清浄器を装備する. } & - & ○ & $\bigcirc$ & $\begin{array}{l}\text { ※ } 3000 \text { PS 以下のみ } \\
\text { 装備 }\end{array}$ \\
\hline 13 & \multicolumn{2}{|c|}{$\begin{array}{l}\text { 過給機注水洗浄装置(ブロアー側, タービン側） } \\
\text { を装備する. }\end{array}$} & - & O & $\bigcirc$ & \multirow{2}{*}{$\begin{array}{l}\text { できるだけ頻繁に洗浄 } \\
\text { を可能にするために装 } \\
\text { 備する. }\end{array}$} \\
\hline 14 & \multicolumn{2}{|c|}{ 空気冷却器洗浄装置を装備する. } & - & 0 & 0 & \\
\hline
\end{tabular}

の仕様の主旨を簡単に説明している.

（2）機関室の装備 低質燃料油使用上，ぎ装は非常 に大きなウエイトを占めている．低質燃料油が問題なく 使用できるか否かは，ぎ装によって決まると言っても過 言ではない。

当社の機関の大部分は低速機関であるため, 燃焼が良 好であり低質燃料油の使用に対しては有利であり機関自 体としての不安は持っていない.

図 1 に 2500 秒油 (RW. No. 1, $100^{\circ} \mathrm{F}$ ) 使用時の燃料処 理系統を示す.

低質燃料油が燃焼すると良質燃料油に比べ燃焼残渣が 多くなる. この燃焼残楂がクランクケース内に入り，潤 滑油の污れや劣化が著しくなってくる. 低質燃料油使用 時の潤滑油の管理はメンテナンス上非常に重要な要素で ある.

困 2 亿潤滑油系統戝を示す.

当社の基準として, 潤滑油ボトムタンクの容量は馬力 当り $2.5 l$ 以上を推奖しており, また潤滑油清浄機の容量 は呼称容量の $1 / 2$ 以下でボトムタンクを含む全油量が一 日に 3〜4 回清浄できる容量を推奖している.

\section{3. 低诈燃料油使用の省燃料形 $E L$ 機関}

低質燃料油が使用でき，また燃料消費率の少ない機関 は, ユーザの要求だけでなくメーカに与えられた最大の 課題である.
当社では，低速 4 サイクルディーゼル機関の特長すな わち信頼性, 耐久性が優れ, 現在むっとも重要視されて いる燃料消費率の低減を図った新形機関の省燃料形 EL 形機関を昭和 54 年に開発した。

$E L$ 形機関は独特の技術開発之試験研究を重ね, 大幅 に燃料消費率の低減を図り，従来の機関に比べ約 $11 \%$ 少 なくなっている.また低質燃料油使用時の機関性能は, 燃 料噴射圧力を高くして噴霧粒子を微細化しているため燃 焼も良好で排気温度やシリンダ内最高圧力などの性能む

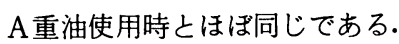

このように, 燃料消費率を減少させ，低質燃料油を使 用するためにつぎのような手段を講じている.

（1）ストロークをシリンダ径の 2 倍としてロングスト ローク化を行い, 膨張行程を長くして熱勃率の向上を図 っている. ロングストローク化すると，回転数はそれに 反比例して低下する.

機関回転数の低下にともなうプロペラ回転数の低下は, プロペラ効率の向上につながる.EL 形機関の回転数は 在来形の同じ出力の機関に比べて約 $10 \%$ 低下しており, プロペラ効率は約 $3 \%$ 向上する.

（2）燃料系統に改善を加え，高圧形の燃料噴射ポンプ を採用して，噴射した燃料油噴霧の微細化を図るととあ に，噴射期間の短縮を図っている。

燃料力ムの形状や噴射弁は最良, 最適のあのを選定し また燃料噴射管の長さは，できるだけ短くするよう配慮 
表 2 機関特別仕様の説明

\begin{tabular}{|c|c|c|}
\hline No. & 明 & 備 \\
\hline 1 & 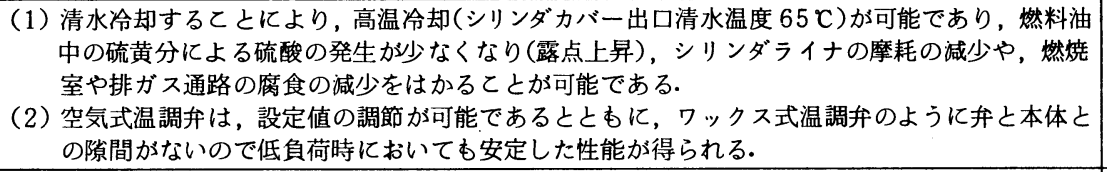 & $\begin{array}{l}400 \text { 秒油より低質 } \\
\text { 燃料油に対する処 } \\
\text { 置 }\end{array}$ \\
\hline 2 & $\begin{array}{l}\text { (1) 燃料供給ポンプが機関付の場合，ポンプのシールが燃料油の加熱温度に弱いこと. また, 燃料 } \\
\text { 噴射ポンプからの脈動により,とのシールが破損するととがあるので供給ポンプは独立とすると } \\
\text { と. } \\
\text { (2) No. } 3 \text { 項の燃料油主管圧力を上げるので，ポンプ圧力あ上昇のとと. }\end{array}$ & \\
\hline 3 & $\begin{array}{l}\text { 燃料油を加熱すると, ベーパーロック現象を生じるが, この現象を少なくするために燃料油圧 } \\
\text { 力を上昇すれば効果がある. }\end{array}$ & \\
\hline 4 & $\begin{array}{l}\text { 主機入口の洰過能力を増加すると共に, 上記べーパーロックをてのとし器で微細化する効果が } \\
\text { ある. }\end{array}$ & $\begin{array}{l}400 \text { 秒油より低質 } \\
\text { 燃料油に適用 }\end{array}$ \\
\hline 5 & $\begin{array}{l}\text { 主機前加熱器と主機までの間でかなりの温度降下があり, この温度降下は温度が高いほど大き } \\
\text { くなる. 2 次こし器や配管をスティーム, 熱媒油, または電気で保温する必要がある. } \\
\end{array}$ & $\begin{array}{l}1500 \text { 秒油より低 } \\
\text { 質燃料油に適用 }\end{array}$ \\
\hline 6 & $\begin{array}{l}\text { 低質燃料油になるほど粘度が高くなるので, 常温では流れにくくなるためスティームトレース } \\
\text { の必要がある. } \\
\text { 燃料油ドレン管(横の配管)に施行する. }\end{array}$ & \\
\hline 7 & $\begin{array}{l}\text { 低質燃料油使用により, ライナー壁面の酸化傾向が強まり，白斑現象が発生することがあるの } \\
\text { で, クロームメッキしライナーを標準としている. }\end{array}$ & \\
\hline 8 & $\begin{array}{l}\text { 排気弁を回転するととにより，カーボンのかみ込みを少なくし，排気弁シート部の温度の均一 } \\
\text { 化をはかり，排気弁の耐久性が向上する. }\end{array}$ & $\begin{array}{l}400 \text { 秒油より低質 } \\
\text { 燃料油に適用 }\end{array}$ \\
\hline 9 & 排気弁ガイドおよびステムの腐食摩耗を減ずる. & \\
\hline 10 & $\begin{array}{l}\text { 機関を何らかの原因で急停止して長時間停泊した之きに, 燃料ポンプ内の燃料油が冷えて固ま } \\
\text { る恐れがある. したがって，ポンプ内を燃料油が循環できるようにす. } \\
\end{array}$ & \\
\hline 11 & $\begin{array}{l}\text { 空気中の水分がシリンダ内に流入するととにより, 腐食を促進するので, できるだけ水分を燃 } \\
\text { 焼室に入れないため. }\end{array}$ & \\
\hline 12 & $\begin{array}{l}\text { 燃料油の比重が重くなるほど, 遠心清浄機の能力が低下するが, 精密洰過器を併用することに } \\
\text { より清浄に効果がある. } \\
\text { こし器形清浄器は, フィルターエレメントへの燃料油の通過流速をおそくしているため, 水分 } \\
\text { およびスラッジの分離に効果があり, 燃料油の安定性を保つ. }\end{array}$ & \\
\hline 13 & $\begin{array}{l}\text { 低質燃料油になるほど, 過給機のよでれが大となり, 機関性能の低下が早くなるので, 過給機 } \\
\text { の注水洗浄装置付とする. }\end{array}$ & $\begin{array}{l}1500 \text { 秒油より低 } \\
\text { 質燃料油に適用 } \\
\end{array}$ \\
\hline 14 & $\begin{array}{l}\text { 機関性能の低下を防止するため, 空気冷却器のよごれを少なくする必要があり,ドックからド } \\
\text { ックの間に掃除を必要とする場合に洗浄しやすくするため. }\end{array}$ & 同 上 \\
\hline
\end{tabular}

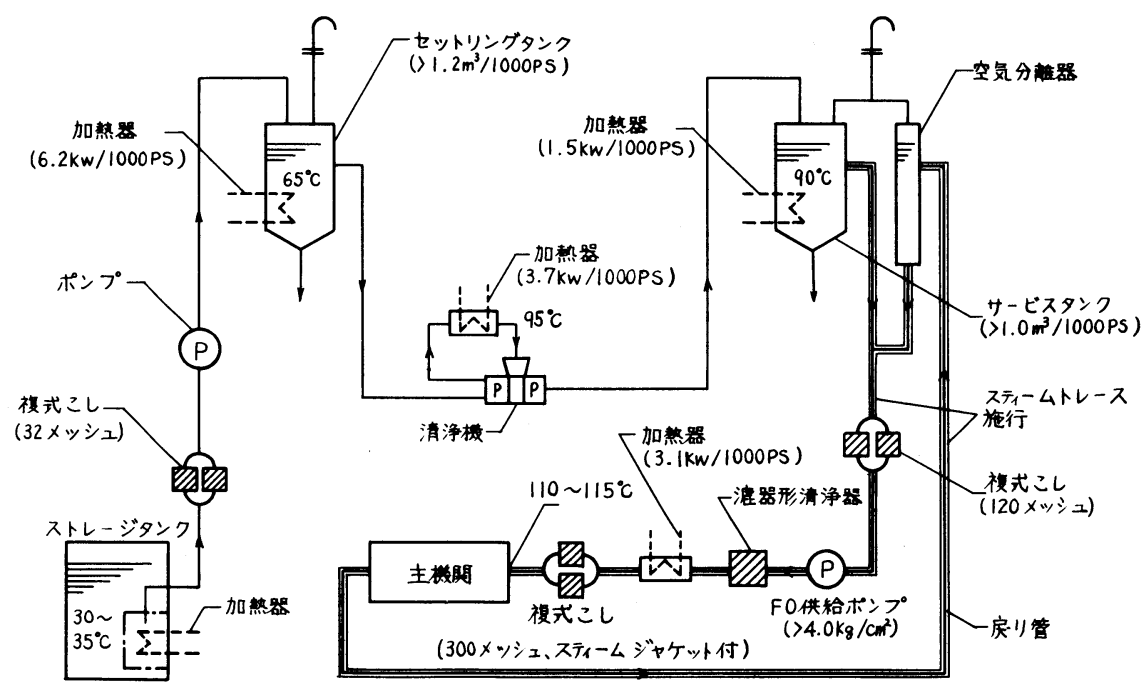

図 12500 秒油 (RW. No. 1, 100 F) 使用時の燃料処理系統 タンクおよび加熱器容量は 1000 PS 当りの容量を示す 


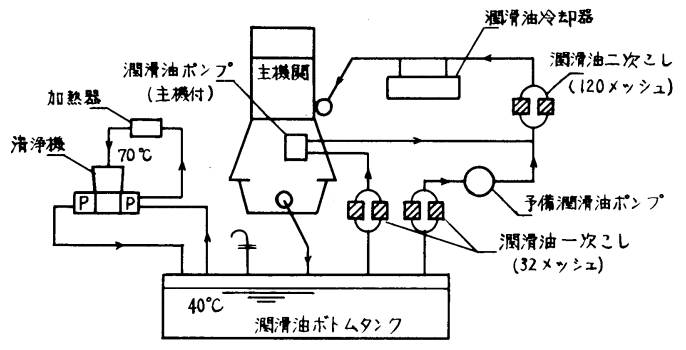

図 2 潤滑油系統図

している.

（3）熱損失を少なくするため，冷却水による冷却損失 を減少させまた性能を向上させるためにシリンダ内最高 珐力を従来より高めて $130 \mathrm{~kg} / \mathrm{cm}^{2}$ とした.

シリンダヘッドやシリンダブロック，機関台板などの 構造物やボルト類, 軸受類は, 剛性を高め充分信頼性の ある設計としている.

$\mathrm{EL}$ 形機関は昭和 54 年に開発以来, 既に 120 台以上 が稼動しており，使用燃料油は 1500 秒油が主流となっ ている. 現在のところ低質燃料油に起因する事故は発生 していないが，ますます低質化する燃料油に対応すべく 今後も最大の努力をするつもりである.

表 3 にEL 形機関の主要目を示す.

\section{4. 在来形 LU 形機関の低啠油対策と低燃費化}

当社では安定した性能と数多くの生産実績を誇る在来 形 LU 形機関に対して，ユーザの御要望にてたえて低燃 費化の検討及び低質燃料油の使用についての検討を進め, 省燃料形 EL 形機関の試験結果を屯とに, 低燃費化の改 造ととあに低質燃料油対策の改造を行った。

LU形機関の改造の要点は,

（1）シリンダ内最高珐力の上昇 サイクルの熱効率 は爆発度が高いほど向上し，燃料消費率は低下する．乙 のためには最高圧力を上げるととが必要よなる。

LU 形機関はその原形を変えるととなく補強を行い, 部品の互換性を考慮し, さらに強度上の余裕を見込んで, シリンダ内最高圧力を上昇させている.

（2）燃料力ムのプロフィル変更従来より使用され ていた等速力ムを減速力ムとしている。

等速力ムは噴射期間中燃料ポンププランジャ速度が等 速で作動するもので, 减速力ムは噴射はじめのプランジ ヤ速度が速く，噴射期間中に速度が減速される.

减速力ムは噴射期間中の初期の噴射圧力が高く，燃料 噴射率の立上がりが早く，噴射期間が短くなり，着火遅 れの改善之後燃え期間が短縮され，低質燃料油の燃焼改 善が行われると同時に燃料消費率を減少させることがで きる.

（3）燃料ポンプのプランジャ径の変更 燃料消費率

表 3 EL 形機関の主要目

\begin{tabular}{|c|c|c|c|c|c|c|c|c|c|c|}
\hline \multirow[t]{2}{*}{ 呼 称 } & \multirow[t]{2}{*}{ シリンダ数 } & \multirow[t]{2}{*}{$\begin{array}{l}\text { 出 力 } \\
(\mathrm{PS})\end{array}$} & \multirow{2}{*}{$\begin{array}{c}\text { 回転速度 } \\
(\mathrm{rpm})\end{array}$} & \multirow{2}{*}{$\begin{array}{c}\text { シリンダ径 } \\
(\mathrm{mm})\end{array}$} & \multirow{2}{*}{$\begin{array}{l}\text { 行 程 } \\
(\mathrm{mm})\end{array}$} & \multirow{2}{*}{$\begin{array}{l}\text { 平均有効 } \\
\text { 压方 } \\
\left(\mathrm{kg} / \mathrm{cm}^{2}\right)\end{array}$} & \multirow{2}{*}{$\left.\begin{array}{c}\text { 燃料消費率 } \\
10200 \mathrm{kcal} / \mathrm{kg} \\
\mathrm{g} / \mathrm{PS} \cdot \mathrm{h}\end{array}\right)$} & \multirow{2}{*}{$\begin{array}{c}\text { 機関重量 } \\
(\mathrm{t})\end{array}$} & \multicolumn{2}{|c|}{$\begin{array}{c}\text { 低質燃料油 } \\
\text { (R.W. No.1,100\%) }\end{array}$} \\
\hline & & & & & & & & & 標準仕様 & 使用限界 \\
\hline $6 \mathrm{EL} 30$ & 6 & 1800 & 300 & 300 & 600 & 21.22 & 143 & 26 & \multirow{5}{*}{1500 秒 } & \multirow{5}{*}{2500 秒 } \\
\hline $6 \mathrm{EL} 32$ & 6 & 2000 & 280 & 320 & 640 & 20.82 & 140 & 30 & & \\
\hline 6 ELS 32 & 6 & 2200 & 280 & 320 & 640 & 22.90 & 140 & 30 & & \\
\hline 6 EL 35 & 6 & 2400 & 260 & 350 & 700 & 20.56 & 138 & 35 & & \\
\hline 6 ELS 35 & 6 & 2600 & 260 & 350 & 700 & 22.27 & 138 & 35 & & \\
\hline 6 EL 40 & 6 & 3300 & 240 & 400 & 800 & 20.52 & 138 & 50 & \multirow{3}{*}{2500 秒 } & \multirow{3}{*}{3500 秒 } \\
\hline $6 \mathrm{EL} 44$ & 6 & 4000 & 220 & 440 & 880 & 20.38 & 135 & 70 & & \\
\hline 6 ELS 44 & 6 & 4500 & 220 & 440 & 880 & 22.93 & 135 & 70 & & \\
\hline
\end{tabular}

表 4 LU形機関の主要目

\begin{tabular}{|c|c|c|c|c|c|c|c|c|c|c|}
\hline \multirow[t]{2}{*}{ 呼 称 } & \multirow[t]{2}{*}{ シリンダ数 } & \multirow{2}{*}{$\begin{array}{l}\text { 出 力 } \\
(\mathrm{PS})\end{array}$} & \multirow{2}{*}{$\begin{array}{c}\text { 回転速度 } \\
(\mathrm{rpm})\end{array}$} & \multirow{2}{*}{$\begin{array}{c}\text { シリンダ径 } \\
(\mathrm{mm})\end{array}$} & \multirow{2}{*}{$\begin{array}{l}\text { 行 程 } \\
(\mathrm{mm})\end{array}$} & \multirow{2}{*}{$\begin{array}{l}\text { 平均有効 } \\
\text { 圧 尘 } \\
\left(\mathrm{kg} / \mathrm{cm}^{2}\right)\end{array}$} & \multirow{2}{*}{$\begin{array}{c}\text { 燃料消費率 } \\
\left(\begin{array}{c}10200 \mathrm{kcal} / \mathrm{kg} \\
\mathrm{g} / \mathrm{PS} \cdot \mathrm{h}\end{array}\right)\end{array}$} & \multirow{2}{*}{$\begin{array}{c}\text { 機関重量 } \\
(t)\end{array}$} & \multicolumn{2}{|c|}{$\begin{array}{c}\text { 低質燃料油 } \\
\text { (R.W.No.1,100 F) }\end{array}$} \\
\hline & & & & & & & & & 標準仕様 & 使用限界 \\
\hline 6 LU 26 & 6 & 1050 & 400 & 260 & 440 & 16.86 & 148 & 13.5 & \multirow{2}{*}{$\begin{array}{l}\mathrm{A} / \mathrm{C} \\
\text { ブレンド }\end{array}$} & \multirow{2}{*}{1000 秒 } \\
\hline 6 LUD 26 & 6 & 1200 & 400 & 260 & 440 & 19.26 & 149 & 13.5 & & \\
\hline 6 LUN $28 \mathrm{~A}$ & 6 & 1400 & 395 & 280 & 480 & 17.99 & 149 & 16.5 & \multirow{2}{*}{$\begin{array}{l}\mathrm{A} / \mathrm{C} \\
\text { ブレンド }\end{array}$} & \multirow{2}{*}{1500 秒 } \\
\hline 6 LUN 28 & 6 & 1600 & 395 & 280 & 480 & 20.56 & 149 & 16.6 & & \\
\hline 6 LU 32 & 6 & 1650 & 340 & 320 & 510 & 17.75 & 148 & 22.2 & \multirow{4}{*}{1500 秒 } & \multirow{4}{*}{2500 秒 } \\
\hline 6 LU 35 & 6 & 2000 & 320 & 350 & 550 & 17.72 & 148 & 27.5 & & \\
\hline $6 \mathrm{LU} 40$ & 6 & 2800 & 300 & 400 & 640 & 17.41 & 144 & 40 & & \\
\hline 6 LUS 40 & 6 & 3000 & 300 & 400 & 640 & 18.65 & 144 & 40 & & \\
\hline
\end{tabular}


は，噴射期間に大きく影響されるもので噴射期間を短く するととが必要ですが，プランジャ径が大きいほど噴射 期間は短くなる. 従来に比べプランジャ径を大きくして いる。

\section{5.むすび}

以上，低速 4 サイクルディーゼル機関の低質燃料油対 策及び燃料消費率の低減について述べたが，この他にも 排熱利用によるトータルとしての省エネルギーも実用化
している。

排熱利用による低質燃料油の加熱源の確保は, 省エネ ルギーシステムとしてのみならず低質燃料油対策の重要 な課題である。

さらに今後の課題として, 機械効率の向上, 冷却水温 度の上昇による熱損失の低减などがあり，またさらに低 質化する燃料油の諸問題に対して充分な対応をする必要 がある。

\section{3. (株)松井鉄工所 ${ }^{*}$}

羽 山昭 三**

\section{1.はじめに}

燃料油価格の高騰から，船舶の運航経費に占める燃料 費の割合は大きなものとなり，運航経済への圧迫は今後 ますます増大してゆく事が考えられます。一方燃料油の 低質化傾向屯避ける事ができない状態で, 中小形ディー ゼル機関の分野まで，C重油の直焚きを初め，A重油上 C重油をブレンドするブレンダー装置を装備する内航船 が急激に増加しているのが現状である。

当社は，舶用ディーゼル主機関を専門に製作している が, 昭和 51 年に開発されたMS 245 シリーズでは,シリ ンダ径 $245 \mathrm{~mm}$ に対し，ストロークを $470 \mathrm{~mm} と し て ，$ ストローク/ボアー比を 1.92 という超ロングストロー クを採用し, 又昭和 53 年にはMU23 型に拄いて, 148 $\mathrm{g} / \mathrm{PS} \cdot \mathrm{h}$ という低燃費機関を製作して，今日の低燃費， 低質油対策上してのロングストローク，低燃費手法を確 立したものとして大きな反響を呼び，その後全幾関にわ たってその技術を活かしてきた。

ここに紹介するML 624GSC型機関は, 従来のMU23 シリーズを高出力化すると共に、エンジン本体は小形軽 量化を図り，低燃費，低質油に対応できる機関として生 産を開始, 漁船, 内航船を問わず幅広く利用するととが できる機関である。

\section{2. 機関の概要}

2.1 機関主要目表 1 亿機関主要目を, 図 1 に 機関の外観を示す.

\section{3. 主要部の構造}

図 2 に機関の横断面を示す.

3.1 台板, 架構本体は 2 分割で, シリンダ部 分とクランク室部分は一体とし, 風性の高い鋳鉄製とし

\footnotetext{
* 原稿受付 昭和 57 年 5 月 24 日

** (株)松井鉄工所(伊勢市竹ヶ鼻町 70)
}

\section{表 1 機関主要目}

\begin{tabular}{|c|c|c|}
\hline 形 & & ML 624 GSC \\
\hline シリン ダ & $\mathrm{mm}$ & 240 \\
\hline 行禿 & $\mathrm{mm}$ & 400 \\
\hline シリン ダ & & 6 \\
\hline 連続定格出一 & PS & 900 \\
\hline 毎 分 回転 & rpm & 420 \\
\hline 平均ピストン速 & $\mathrm{m} / \mathrm{s}$ & 5.6 \\
\hline 正味平均有効圧， & $\mathrm{kg} / \mathrm{cm}^{2}$ & 17.8 \\
\hline シリンダ内最大压フ & $\mathrm{kg} / \mathrm{cm}^{2}$ & 105 \\
\hline 機関寸法 全 & $\mathrm{mm}$ & 4036 \\
\hline 全 & $\mathrm{mm}$ & 1395 \\
\hline 高 & $\mathrm{mm}$ & 1632 \\
\hline 重 & TON & 10.5 \\
\hline
\end{tabular}

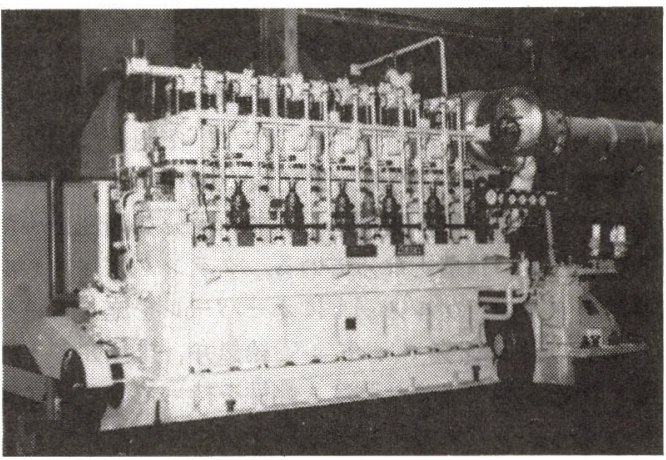

図 1 ML624 GSC型外観

た、振動，強度面において全く心配のない事が確認され ている.

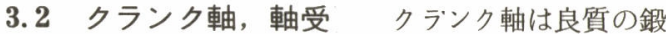
鋼を使用し, シリンダピッチとシリンダ径の比は 1.4 と 詰めてあり，比較的太い軸径としている。このため捩り 振動, デフレクションも少なく剛性上良好な結果を得て いる. 軸受は薄肉メタルでケルメットを使用し, オーバ ーレを施している. 